\title{
I. ARTYKULY
}

\author{
STEVEN WILF
}

\section{FROM PUBLIC DOMAIN TO PUBLIC INTEREST}

The copyright public domain is yesterday's cause. Once the clarion call of a generation of scholars, civil society policy advocates and open access gurus, it has lost its special status to public interest. This brief essay is an exploration of how the public domain came to achieve its place as a focus of attention, how it shaped a generation of scholars, and why public interest might be a more salient construct for thinking about how to foster a public-directed system of global knowledge governance. In short, this is the story of the rise, fall, and reincarnation - as public interest - of the public domain.

At first glance, the public domain seems as real as any topographic boundary-marking feature such as mountains or rivers. The public domain, at least as envisioned by its proponents, was a vast expanse that had existed before it was intruded upon by a variety of grants to private copyright owners. Restricting the public domain may have begun in the beginning of the eighteenth century in Europe with the passage of the British Statute of Anne in 1710. During the nineteenth century, legislatures and courts extended copyright to derivative works, introduced new subject matters such as musical and theatrical performances, and provided new mechanisms for policing and enforcing copyright protection - including criminal prosecution for infringement. The twentieth century has witnessed an even greater extension of ownership over knowledge assets. Intellectual property scholar Robert Merges has called intellectual property's last century 'a hundred years of solicitude'. ${ }^{1}$

Despite valid concerns over intellectual property maximalism, however, boundary tending for the public domain simply has not proved successful for two major reasons. First, as Pamela Samuelson and others point out, the very definition, cartography and justification of the commons have proved difficult to ascertain. It is, states one observer, nothing but a 'mishmash.'2 Second, private technological ordering augmented traditional copyright. Digital gatekeeping through Digital Rights Management (DRM) technolo-

\footnotetext{
1 Merges (2000): 2187-2240; Wilf (2013): 441-459.

${ }^{2}$ Ochoa (2002): 221.
} 
gies bolstered by statutory regimes such as the United States Digital Millennium Copyright Act DMCA) undermined much of the movement to protect and, perhaps, even expand the public domain. ${ }^{3}$ The debate over the terms of copyright was sidelined by a much larger placing of information assets in digital lockboxes that could not be accessed without the permission of their owners.

The public domain was born out of a sense of urgency. 'There are too many IP rights; they are too strong', says Merges, summing up this sentiment. 'Something has to be done.' ${ }^{4}$ But is the solution the public domain or is there emerging a new approach to fashioning a public-regarding copyright framework? I will suggest that the very conception of the public domain as a territorial space is a mistake. Creating two realms for knowledge - one public, open and unfunded and the other - private and rent-seeking - does a disservice to the public welfare. The history of the public domain is one of growing recognition, from the eighteenth century onwards, of the public as a stakeholder. In its beginning, intellectual property historians recognized the contingent and mythological aspects of centering copyright upon romantic authorship. Might the public also have a conceptual centerpiece? With the rise in the 1980s of the Second Enclosure and the social movement that emerges in response, copyright policy experts adopted some of the commonplace tropes of the legal field - property as a metaphor and territoriality and fashioned an alternative space where copyright does not impair the use of expression by others.

This article is divided into two parts. Part One, Making the Public Domain: Metes, Bounds, and Metaphors interrogates this checkered history of the public domain. The second part, The Rise of Public Interest, examines how public interest has supplanted the public domain. It discusses how the failure to establish a protected copyright public domain in the course of two copyright term cases decided by the United States allowed for the turn to public interest. It argues that the debacles suffered in these cases, Eldred $v$. Ashcroft and Golan v. Holder, actually created the opening for robust interventions in support of the public interest. Charting the shift from public domain to public interest, this section points to recent cases where international and domestic United States law became increasingly public-regarding. Finally, I suggest that the loss of a separate world apart for the public domain might in the end create the legal conceptual space for public interest to flourish.

${ }^{3} 17$ U.S.C. $§ 1201$ (1999). The DMCA resembles other DRM systems since its passage fulfilled the international obligations assumed by the United States under the World Intellectual Property Organization (WIPO) Copyright Treaty, which required member states to 'provide adequate legal protection and effective legal remedies against the circumvention of effective technological measures that are used by authors in connection with the exercise of their rights.' Berne Convention for the Protection of Literary and Artistic Works, art. 11, Dec. 20, 1996, S. Treaty Doc. No. 99-27 (1986), 1161 U.N.T.S. 3.

${ }^{4}$ Merges (2004): 183. 


\section{MAKING THE PUBLIC DOMAIN: METES, BOUNDS, AND METAPHORS}

Intellectual property, of course, might be considered rights (themselves intangible) over an intangible - which rests on a rhetorical trope that is particularly intangible: intellectual property as property. Not surprisingly then, copyright - which early nineteenth-century United States Supreme Court Justice Joseph Story called 'the metaphysics of the law' - required some rhetorical bootstrapping to other areas of legal doctrine through metaphors and analogies. ${ }^{5}$ Metaphor is a figure of speech where one concept is expressed through a word or phrase deployed for something quite dissimilar. It suggests an imagined commonality. Copyright is chock-full of metaphors. This area of law's dramatis personae includes such children's literature characters as pirates and trolls; works might be orphaned; and, when discussing satellite communications transmission, the United States Supreme Court has no hesitation in deploying a duck test. ${ }^{6}$

By its very name, intellectual property draws upon a connection to other forms of property such as land and chattel. ${ }^{7}$ The term intellectual property was first used in the United States in the 1840s to justify a person's ownership in knowledge similar to "the wheat he cultivates or the flocks he rears.' ${ }^{\text {Much }}$ has been said about unsuitable use of real property as a model for copyright and patent. ${ }^{9}$ Despite the commonplaces of metes and bounds, the right to exclude, and adverse claims in the course of exceptions of limitations, a list of the differences between real and intellectual property might easily be constructed.

A large body of scholarship identified the emergence of romantic authorship that understood creation as a private and deeply subjective enterprise. It identified a particular narrative of producing works - claiming that, writers fashioned their works independently and paid little heed to the substantial reliance on the existing writings of others. The expressive act was embedded in a network of cultural practices. While romantic authorship notions endorse the doctrine of natural rights over one's own creation as private, subjective, expressive, and perpetual, utilitarian theory promotes dissemination to the public, the objective nature of knowledge, competition, and limits on rights. The historical turn in copyright was deeply influenced by currents in literary new historicism. The focus of the leading figures interrogating the concept of romantic authorship, such as Peter Jaszi and Martha Woodmansee, was upon natural rights justifications for what existed within the framework of protection. The very private nature of romantic authorship led to an imagin-

${ }^{5}$ Folsom v. Marsh, 9 F. Cas. 342, 344 (1841).

${ }^{6}$ American Broadcasting Cos., Inc. v. Aereo, Inc., 573 U.S. 134 S. Ct. 2498 (2014). The classic Duck Test states: 'If it looks like a duck, swims like a duck, and quacks like a duck, then it probably is a duck.' On intellectual property metaphors in general, see Frye (2015).

7 Stern (2012): 113-150.

${ }^{8}$ Davoll et al. v. Brown1 Woodb. \& M. 53, 7 F.Cas.197 (1845).

9 See, for example, Lemley (2005): 1036-1037. 
ing of a space - hence the importance of the use of the term 'domain' - for the public sphere. Public domain might be defined as simply what was left behind as owners justified privatization through asserting the presumed claims of authors.

During the early 1980s, a nearly simultaneous social movement emerged to define and protect the intellectual property public sphere. David Lange's article, Recognizing the Public Domain, galvanized others to consider the magnitude of books, music, and plays that simply were removed from unfettered public access. ${ }^{10}$ It was not as if the public domain did not exist prior to the last four decades. Indeed, Isabella Alexander convincingly shows that the focus on the public interest might have emerged in the nineteenth century as a response to an emphasis on authorial rights. ${ }^{11}$ Yet there is a difference between an existing de facto public domain as defined by factors such as failure to meet minimal requirements or the removal of protection at the end of a defined copyright term - and perceiving the public domain. It is not surprising that Lange spoke of recognition as essential to the construction of an entirely distinct sphere.

Lange's pioneering contribution was followed by Jessica Litman's The Public Domain. Litman's masterful piece was particularly influential. The article drew upon the critique of romantic authorship to focus on the practical legal endeavor of setting boundaries for protection. As Litman details, creative works are not produced by authors operating in a vacuum. They are constructed from materials common to all. ${ }^{12}$ While those probing the limits of romantic authorship largely saw this sphere as simply outside copyright, Litman pointed out how the public domain itself must be protected and governed by copyright rules. She demonstrated how copyright's public domain is justified within the line-drawing that emerges from the entirety of the creative process.

\section{The Second Enclosure}

Critics of copyright maximalism often critique the notion of intellectual property rights as property rights. Yet the very word "domain" comes from the Latin term dominus (embodied in the medieval English demesne) that suggests a fiefdom owned by a Lord. It is therefore ironic that much of the turn towards the public domain nearly two decades ago drew upon real property analogies and identified its period as the Second Enclosure. Drawing on the shift in land ownership in early modern England, James Boyle argued that intellectual property was also losing its commons. In the late sixteenth and early seventeenth century, there was a transformation in the methods of arable farming from a system of open fields, often used for pasturing, to a deeded plots. Access to wooded areas was limited. Called enclosure, this process had a major adverse impact as it constrained the ability of farmers to draw upon

\footnotetext{
10 Lange (1981).

11 Alexander (2010).

12 Litman (1990): 965-1023.
} 
the broader natural resources available in a region. Boyle saw the privatization of the intellectual property public domain as a similar loss of the commons. ${ }^{13}$

The idea of a Second Enclosure borrowed a metaphor from real property. It also gestured to the manifold forms of resistance that emerged in seventeenth-century England in response to enclosure, such as the Midland Revolt of the early 1600s, the Western Rising of the 1630s, and even the English Civil War. The conflict over the closing of the commons has particular resonance as a progressive political narrative. It dovetailed with the growing prominence of social historians, especially of the Past and Present School such as E.P. Thompson and Christopher Hill, who saw the anti-Enclosure movement as a critical strand of English history. Yet the Second Enclosure also raises the possibility of thinking about copyright law in ecological terms. Copyright is considered a cornerstone of cultural environmentalism. ${ }^{14}$ One commentator wrote darkly about 'the continual desertification of the reproduction oasis of human culture. ${ }^{15}$ It has become commonplace to speak of digital ecosystems. Even Samuelson's project of mapping the knowledge commons - creating a cartography of the public domain - speaks to the idea that copyright fundamentally address environmental policy issues. ${ }^{16}$

Boyle summarized the relationship between the public domain and ecological political movements: similar to "the environment, the public domain must be "invented" before it is saved. Like the environment, like "nature," the public domain turns out to be a concept that is considerably more slippery than many of us realize. And like the environment, the public domain nevertheless turns out to be useful, perhaps even necessary.' ${ }^{17}$ The public domain only comes into existence when it is recognized by others. Indeed, it has been argued that the first enclosure movement in the seventeenth century did not simply impair the access of ordinary citizens to common land. It obscured in legal cultural terms the very notion that there might be non-exclusive property that was accessible by anyone. As has been pointed out, such a shift of perception might be taking place during the Second Enclosure of intellectual property as well. ${ }^{18}$

The Second Enclosure argument was a call to arms for establishing a new intellectual property social movement. Indeed, its legacy can be seen in European Pirate parties, the Open-Source-Software movement, and NGOs such as the Electronic Frontier Foundation. Yet what do we mean by the public domain? David Lange, whose 1981 article is credited with launching the contemporary commitment to safekeeping the public domain, admits in a retrospective article that the definition of the public domain is 'elastic and inexact'. ${ }^{19}$ Was it simply a way of readdressing the distributive aspect of information

\footnotetext{
13 Boyle (2003); see also, Benkler (1999).

14 Cunningham (2010): 2.

15 Huang (2009): 178-195.

16 Samuelson (2006): 7-25.

17 Boyle (2003): 72-73.

18 Rose (2003): 91.

19 Lange (2003): 463.
} 
assets? America's vast nineteenth century public domain rested upon two essential columns. First, a formalist copyright regime that left much expressive writing in the public domain simply because creators failed to seek copyright protection. ${ }^{20}$ Such formalism often turned out to be a stumbling block to the unwary who failed to pursue copyright registration simply because they were less well-versed in the legal technicalities or not the sort of creator who often has recourse to the professional advice of lawyers.

Secondly, it is impossible to underestimate the importance of nineteenth-century copyright piracy for enabling the creation of the United States public domain. Prior to the passage of the Chase Act of 1891, the vast majority of American imprints were works by British authors who were denied copyright protection - and any sort of royalty. ${ }^{21}$ As Robert Spoo has suggested, the nineteenth-century United States public domain was 'a vast opportunistic literary commons assembled from the legal have-nots of foreign authorship and reflecting the protectionist policy of a developing nation in quest of instant and assured culture. Created by United States copyright laws, the American public domain was nothing less than an aggressively legislated commons, an invitation to privacy that served the interest of domestic publishers' and others. ${ }^{22}$

Public domain is a relatively new term. In United States law, it appeared in the 1909 Copyright Act to describe the works that could not be protected through copyright renewal and therefore would be freely available for general use. ${ }^{23}$ As Tyler Ochoa has shown, Judge Learned Hand was responsible for the emergence of the public domain as a concept in copyright law. He deployed the term in a dozen published cases between 1915 and $1924 .^{24}$ Both the 1909 Act and Judge Hand seem to have transplanted the rhetoric of the public domain into United States law by directing translating the French domaine public. Slowly, yet with increasing velocity, it appeared that the notion of public domain would join other core copyright doctrinal frameworks. Within a few decades of Lange's, Litman's, and Boyle's pathbreaking work, a coherent body of justifications for the public domain were firmly in place. Moreover, by the turn of the millennium scholars, particularly Pamela Samuelson, had embarked upon a major project of mapping the public domain. ${ }^{25}$ The groundwork had been laid in courts and scholarly research. Towards the end of the $1990 \mathrm{~s}$, the United States Congress decided to extend the duration of protection, and it appeared that this would be the defining moment for solidifying the public domain. Would a Supreme Court decision in response to the new statute provide the public domain's Constitutional foundation? Yet challenging the new Congressional statute proved to be a fiasco for the construction of public domain arguments.

\footnotetext{
20 Sprigman (2004).

${ }_{21}$ On the international copyright problem in general, see Seville (2006) Spoo (2013). Chace Act of 189126 Stat. 1106, March 3, 1891.

22 Spoo (2013): 3.

23 Cong. Ch. 60-320, § 23, 35 Stat. 1075, 1080 (1909). Ochoa (2002): 226.

24 Ochoa (2002): 243.

25 Samuelson (2003): 148.
} 


\section{THE RISE OF PUBLIC INTEREST}

In 1998, the United States Congress enacted the Copyright Term Extension Act (CTEA). It extended the copyright term from the life of the author plus 50 years, as previously under the 1976 Copyright Act, to the life of the author plus 70 years. For works of corporate authorship, the duration of the term was extended to 120 years after creation, or 95 years after publication, whichever date is reached earlier. As a result of this statute, no works would enter the public domain until 1 January 2019. ${ }^{26}$ Although the existing duration of copyright in the United States was well within the life plus 50 years duration set forth in the Berne Convention, Article 7.1, the CTEA was intended to harmonize the United States' copyright term with Europe's Copyright Duration Directive. ${ }^{27}$ The notion of freezing the public domain for twenty-one years was a significant setback to the idea of expanding public access to copyrighted works. Critics pointed out that the Disney character Mickey Mouse would remain under copyright until 2024 and, because the extension was blamed on corporate interests, the statute was derisively labelled the Mickey Mouse Protection Act.

Very quickly, the CTEA came under attack from a coalition consisting of public domain advocates and copyright scholars. Richard Stallman's Free Software Foundation and Harvard University's Berkman Center for Internet \& Society were stalwart opponents of the statute. It was particularly troubling that in 1998, the very year the CTEA came into effect, Congress also passed the Digital Millennium Copyright Act (DMCA). The DMCA criminalized the making and dissemination of technology, devices, or services that might be used to circumvent access control mechanisms (DRM) as well as the act itself of circumventing access controls. ${ }^{28}$ Criminal penalties are imposed whether or not there is actual copyright infringement. Enormous amounts of public domain material were placed behind digital barriers and rents were extracted from those who sought access. Clearly, 1998 was an annus horribilis, a watershed moment to galvanize political and legal forces for the protection of the public domain. ${ }^{29}$

A law suit was launched with an internet publisher as the name plaintiff, Eric Eldred. It is clear even from the initial court case that the plaintiffs in what would become Eldred v. Ashcroft would make capacious constitutional arguments about the failure of retroactive copyright term extension to further the goals of copyright for the creation and dissemination of works. ${ }^{30} \mathrm{In}$

${ }_{26}$ Pub. L. No. 105-298, 112 Stat. 2827 (1998) (codified as amended in various sections of 17 U.S.C. including $\$ \S 101-106,203,301-304)$.

27 Council Directive 93/98/EEC of 29 October 1993 harmonizing the term of protection of copyright and certain related rights

2817 U.S.C. $§ 1201$ (1999).

29 Sonny Bono Copyright Term Extension Act, Pub. L. No. 105-298, tit. I. 112 Stat. 2827 (CTEA).

30 Eldred v. Reno, 74 F.Supp.2d 1 (1999). 
other words, the public domain should consist of all material where a compelling argument for protection could not be made. Three arguments animated the plaintiff's approach. First, retroactive copyright violated the purposeful requirements of the Constitution's Intellectual Property clause for 'promoting the progress of science and useful arts . . . for limited times. ${ }^{31}$ It failed, secondly, to provide the proper balance under the First Amendment between copyright stakeholders and freedom of speech. Third, it ran counter to the public trust doctrine that obligates the government to show public benefit when property is taken from the public. These arguments shift the justificatory burden to copyright itself - can those claiming protection, from the point of view of expression or property, justify asserting intellectual property rights? The public domain under this conception is a negative space: everything that cannot be claimed.

This argument was an attempt to construct a copyright bargain akin to the patent bargain. The Supreme Court decision explicitly rejected this approach: 'Patents and copyrights do not entail the same exchange, since immediate disclosure is not the objective of, but is exacted from, the patentee, whereas disclosure is the desired objective of the author seeking copyright protection. Moreover, while copyright gives the holder no monopoly on any knowledge, fact, or idea, the grant of a patent prevents full use by others of the inventor's knowledge'. ${ }^{32}$ The decision pointed out the many instances where Congress had mandated a retrospective copyright term extension. More important for proponents of the public domain, was that its definition was assigned to Congress. Justice Ruth Bader Ginsburg, writing for the majority stated unequivocally that 'the Copyright Clause ... empowers Congress to define the scope of the substantive right'. By defining the scope of copyright, the legislature also sets the metes and bounds of the public domain.

Eldred proved a major setback for the idea that the public domain exists as a space unencumbered by intellectual property rights as a territory apart from copyright. Instead, the Supreme Court viewed it as a mirror of statutory rights. It identified a residual public domain - merely what is left after everything else is taken. But this should have come as no surprise. Beyond the narrow evidence of historical precedence for extending the duration of copyright, there is the Anglo-American predilection for seeing intellectual property as positive law defined by the legislature and courts. Indeed, perhaps one of the most important Supreme Court intellectual property decisions of the twentieth century, Sears-Compco, explicitly states that the Patent Act defines not just what is patentable - but also what stands outside of protection. ${ }^{33}$ If this is true for patent, why not for copyright as well?

31 Art. I, Sec. 8, cl. 8 .

32 Eldred v. Ashcroft, 537 U.S. 186, 190 (2003).

33 Sears, Roebuck \& Co. v. Stiffel Co., 376 U.S. 225 (U.S. 1964) and Compco Corp. v. DayBrite Lighting, Inc., 376 U.S. 234 (U.S. 1964). 


\section{Vertiginous Law on the Golan Heights}

There would be a second round in this struggle. The Supreme Court's 2012 decision Golan v. Holder again addressed the Constitutional 'limited times' provision. ${ }^{34}$ It involved a challenge to the constitutionality of applying Section 514 of the Uruguay Round Agreements Act (URAA). ${ }^{35}$ The Uruguay Round treaty sought to create a level playing field for international copyright. Its particular impact upon the United States was that it extended copyright protection to foreign works that already had fallen into the American public domain. The United States previously had resisted the restoration of copyright for public domain foreign works. When adopting the URAA, it created a complex set of administrative procedures where such works were already used by good faith users..$^{36}$ Rightsholders would be required to file a Notice of Intent to Enforce (NIE) to these good faith users, called reliance parties, and negotiations would proceed over determining royalties. If no agreement was reached, courts might intervene and determine a fair licensing fee.

Challenging this statute, the plaintiffs reprised the 'limited times' argument from the Constitution's Intellectual Property clause and the First Amendment freedom of expression argument. Again, a roster of NGOs, including the Electronic Frontier Foundation and Creative Commons, and intellectual property scholars, sought to establish a protected public domain. Justice Ginsburg, who authored the majority opinion for Golan as well as Eldred also treated it as a second act in an ongoing drama. She referenced the already decided approach in Eldred to grant broad Congressional power to define the contours of copyright. Marshalling historical precedent, much as in Eldred, Justice Ginsburg pointed out that promoting the progress of science and the useful arts might entail more than simply establishing incentives for the creation of new works.

Golan was seen as an utter rout for public domain advocates. Indeed, it was viewed as even more devastating than Eldred because it was not simply that copyright was extended for works that would ordinarily have entered the public domain. It actually removed music and literary writings from the public domain where parties had relied upon their availability to anyone who wished to use them. Certainly, Golan has been pilloried as an example of an overly protectionist decision. Yet Golan might be seen as an opportunity to pivot from public domain to public interest. Clearly, an important factor motivating the Court's opinion was United States adherence to an international framework for copyright.

In its beginnings, copyright was a metropolitan law, a territorial legal apparatus where enforcement ended at national borders. ${ }^{37}$ The United States was a reluctant participant in global copyright governance. Although the Berne Convention for the Protection of Literary and Artistic Works was founded

\footnotetext{
${ }^{34}$ Golan v. Holder, 132 S.Ct. 873 (2012).

35 Pub.L. 103-465, 108 Stat. 4809.

3617 U.S.C. $\S 104 \mathrm{~A}$.

37 Wilf (2013): 441-459.
} 
in 1886, the United States only became a signatory over a century later, in 1998. ${ }^{38}$ Prior to the passage of the Chace Act of 1891, American publishers relied largely upon reprinting British works without remunerating their authors. It was considered the Barbary States of intellectual property, readily willing to pirate editions from abroad. Even after adopting the Berne Convention, the United States was dubiously compliant in some doctrinal areas such as moral rights.

The most radical element of Justice Ginsburg's Golan opinion was that the all-so-very-American Constitutional provisions for intellectual property provided the grounding for an insistent membership in the institutions and legal doctrines of global governance. According to Justice Ginsburg, 'Congress had reason to believe that a well-functioning international copyright system would encourage the dissemination of existing and future works. ${ }^{39}$ Copyright restoration under the Uruguay Round negotiations was simply the price tag for participating in Berne and the international copyright framework.

It is important to identify the possibilities inherent in this point of departure. If copyright protection falls within the ambit of international norms, then the United States also might be obligated to engage European Union concerns with establishing a more public-regarding copyright system. For example, the United States might consider the Court of Justice of the European Union's (CJEU) use of proportionality. In Football Association Premier League and Others, the court emphasized the need to balance the interests of rightholders and users of information..$^{40}$ Public interest might emerge around issues of access to information and user rights. ${ }^{41}$ Should we embrace a broad definition of public interest in order to broaden standing in copyright infringement cases - much as we do in environmental law? ${ }^{42}$

Unlike the copyright public domain, public interest intervenes within virtually every aspect of copyright legal doctrine. It is deeply embedded in copyright law. Should standing in court cases be broadened to provide for public stakeholders much as is commonly the case in the sphere of environmental law? Should we apply the principles of public interest to demanding proportionality in civil and criminal sanctions for copyright infringement? Public domain proponents frequently quote Justice Louis Brandeis's dictum that intellectual property should remain as free as air. ${ }^{43}$ The public domain should be defended from encroachments. It follows Isaiah Berlin's definition of negative liberty - freedom from interference. Yet the emergent discourse of public interest demands just the opposite: a constant encroaching on private grants of

${ }^{38}$ Berne Convention Implementation Act of 1988, Pub. L. No. 100-658, 1988.

${ }^{39}$ Golan v. Holder, 132 S.Ct. 873, 876 (2012).

${ }^{40}$ Football Association Premier League and Others, C-403/08 and C-429/08, EU: C: 2011:631, paras 163-164. Rosati (2019): 52-54.

${ }^{41}$ World Intellectual Property Organization Copyright Treaty, adopted by the Diplomatic Conference on December 20, 1996 (SI 2005/3431). An enormous literature has emerged around Access to Knowledge. But see, in particular, Kapczynski (2008): 826-827.

${ }^{42}$ Jacobs (2014): 427.

${ }^{43}$ International News Service v. Associated Press, 248 U.S. 215, 250 (1918). 
rights. Jane Ginsburg has asked why authors and the public are understood as competing objectives. ${ }^{44}$ Public interest asks how public welfare might be fostered even when authors own and benefit from copyrighted materials.

An example of this might be the recently enacted 2013 Marrakesh Treaty to Facilitate Access to Published Works by Visually Impaired Persons and Persons with Print Disabilities (MVT). ${ }^{45}$ An important element in the treaty is the designation of authorized entities, trusted governmental and non-profit organizations vested with serving as public interest intermediaries. They are charged with duties of identifying authorized beneficiaries, providing copyrighted materials in formats that would benefit such persons, discouraging unauthorized uses of copies, and establishing best practices to maintain due care in handling copyrighted works.

Bolstered by Golan, international agreements are one portal for public interest norms to enter United States law. But there is growing evidence that public-regarding is showing up in a variety of surprising places. In a number of cases, the Supreme Court has shown a willingness to impose attorney fees as a mechanism of discouraging frivolous copyright infringement suits. In Kirtsaeng v. John Wiley \& Sons, Inc. (2016) the United States Supreme Court upheld the idea that copyright's public interest goals should be considered as guiding principles when determining attorney fees. Quoting an earlier case, the Court wrote 'copyright law ultimately serves the purpose of enriching the general public through access to creative works . . . [and] achieves that end by striking a balance between two subsidiary aims: encouraging and rewarding authors' creations while also enabling others to build on that work. ${ }^{46}$

Even more striking is the applicability of public interest when courts provide injunctive relief under Section 502 of the 1976 Copyright Act. In determining whether to issue a preliminary injunction, courts have generally examined (1) whether the plaintiff will have an adequate remedy at law or will be irreparably harmed if the injunction does not issue; and (2) whether the threatened injury to the plaintiff outweighs the threatened harm the injunction may inflict on the defendant; and (3) whether the plaintiff has at least a reasonable likelihood of success on the merits. ${ }^{47}$

Following the Supreme Court's 2006 patent decision eBay Inc. v. MercExchange, L.L.C., courts adopted a new public-regarding fourth prong when evaluating a motion for a preliminary injunction in copyright infringement cases: whether the granting of a preliminary injunction will disserve the public interest. ${ }^{48}$ This opens a door for courts to examine the public interest in a vast number of new cases. While Salinger $v$. Colting remains exceptional at this juncture, it does suggest how public interest increasingly might play an important role in copyright law. In this case, Fredrik Colting wrote an unauthorized sequel to J.D. Salinger's classic novel, Catcher in the Rye (1951).

\footnotetext{
${ }^{44}$ Ginsburg (1997).

${ }^{45}$ Land (2018).

46136 S.Ct. 1979 (2016).

47 Nimmer on Copyright $\S 14.06$.

${ }^{48} 547$ U.S. 388 (2006).
} 
Entitled 60 Years Later Coming through the Rye, it provides a glimpse of what happens to a youthful rebel as he ages. In copyright terms, as a sequel it is a garden variety derivative work. Salinger, now represented by his trustees, sought a preliminary injunction. The United States Court of Appeals for the Second Circuit, which heard the case, envisioned a robust role for the new eBay public interest prong: the 'public's interest in free expression . . . is distinct from the parties' speech interests . . . Every injunction issued before a final adjudication on the merits risks enjoining speech protected by the First Amendment. ${ }^{49}$ If not Holden Caulfield, the troubled protagonist of the novel, then public interest seems to have come of age.

\section{CONCLUSION}

In 2004, a number of proponents of the public domain introduced Public Domain Day on 1 January. This is the day that copyrighted works would enter the public domain. Poland, Germany and Israel are among the many countries where the day has been marked. Perhaps the holiday is simply too new for there to be well-established customs. Even New Year's Day itself seems impoverished, with private fireworks and Polar Bear Club plunges into icy waters. Until 1 January 2019, there was not much to celebrate. On that date the freezing of works entering the public domain, as a consequence of the passage of the Copyright Term Extension Act in the United States, came to the end. A number of well-known literary and musical creations entered the public domain: Kahil Gibran's The Prophet, works by Virginia Woolf and Agatha Christie, Robert Frost's New Hampshire, and music by Noel Coward and George Gershwin. On 1 January 2020, Thomas Mann's Magic Mountain and E.M. Forster's Passage to India made their own passage to that vast conceptual territory known as the public domain. In 2021, they will be joined by F. Scott Fitzgerald's The Great Gatsby and Virginia Woolf's Mrs. Dalloway. ${ }^{50}$

In truth, there is little to celebrate. The public domain project has stalled. This article has traced its beginnings from being a counterpoint to the rise of the romantic author to its envisioning from the 1980s onwards by Lange, Boyle, and Litman, how it came to adopt its own set of metaphors such as the Second Enclosure, the cartographic enterprise by Samuelson and others to map its contours, and the various NGOs that flocked to its banners. The rise of the public domain, however, proved to be illusory. With two major Supreme Court cases, Eldred v. Ashcroft and Golan v. Holder, its advocates suffered a major debacle. Was nearly three decades of effort to conceptualize and chart the public domain merely gossamer - an ethereal attempt to fashion a pub-

49 Salinger v. Colting, 607 F. 3d 68, 82-83 (2d Cir. 2010).

${ }^{50} \mathrm{Liu}$ (2013). 
lic-regarding copyright? Just a decade into the new millennium the dream of an information commons seemed ever more elusive.

I have suggested that these cases held within them the germ of a new tilt towards public interest. We are just beginning to see the rise of public interest taking shape. It seems that champions of the public welfare just might be able to snatch victory from the jaws of defeat.

\section{Steven Wilf}

University of Connecticut

and Princeton University, USA

swilf@princeton.edu

Alexander, I. (2010). Copyright Law and the Public Interest in the Nineteenth Century. Cumnor: Hart Publishing.

Benkler, Y. (1999). Free as air to common use: First Amendment constraints on enclosure of the public domain. New York University Law Review 74(2): 354-436.

Boyle, J. (2003). The second enclosure movement and the construction of the public domain. Law \& Contemporary Problems 66(1/2): 33-74.

Cunningham, R. (2010). The tragedy of (ignoring) the information semicommons: a cultural environmental perspective. Akron Intellectual Property Right Journal 4(1): 1-33.

Frye, B.L. (2015). IP as metaphor. Chapman Law Review 18: 735-758.

Ginsburg, J. (1997). Authors and users in copyright, Journal of the Copyright Society 45: 1-20.

Huang, H. (2009). On public domain in copyright law. Frontiers of Law in China 4(2): 178-195.

Jacobs, R.W. (2014). In privity with the public domain: the standing doctrine, the public interest, and intellectual property, Santa Clara High Tech Law Journal 30(3): 415-467.

Kapczynski, A. (2008). The access to knowledge mobilization and the new politics of intellectual property. Yale Law Journal 117(5): 804-885.

Land, M.K. (2018). The Marrakesh treaty: 'bottom-up' lawmaking: supporting local human rights action on IP policy. University of California Irvine Law Review 8(3): 513-553.

Lange, D. (1981). Recognizing the public domain. Law \& Contemporary Problems 44(Fall): 147178.

Lange, D. (2003). Reimagining the public domain. Law \& Contemporary Problems 66(1/2): 463-483.

Lemley, M.A. (2005). Property, intellectual property, and free riding. Texas Law Review 83: 10311076.

Litman, J.D. (1990). The public domain. Emory Law Journal 39(Fall): 965-1023.

Liu, J.P. (2013). The new public domain. University of Illinois Law Review 2013(4): 1395-1456.

Merges, R. (2000). One Hundred Years of Solicitude: intellectual property law 1900-2000. California Law Review 88: 2187-2240.

Merges, R. (2004). A new dynamism in the public domain. University of Chicago Law Review 71: $183-203$.

Ochoa, T.T. (2002). Origins and meanings of the public domain. University of Dayton Law Review 28: $215-266$.

Ochoa, T.T. (2002). Origins and meanings of the public domain. University of Dayton Law Review 28(2): 215-267.

Rosati, E. (2019). Copyright and the Court of Justice of the European Union. Oxford: Oxford University Press.

Rose, C. (2003). Romans, roads, and romantic creators: traditions of public property in the information age. Law \& Contemporary Problems 66(1/2): 89-100.

Samuelson, P. (2003). Mapping the digital public domain: threats and opportunities. Law \& Contemporary Problems 66(1/2): 147-171.

Samuelson, P. (2006). Challenges in mapping the public domain, [in:] L. Guibault, P.B. Hugenholz (eds.), The Future of the Public Domain: Identifying the Commons in Information Law. Alphen aan den Rijn: Kluwer Law International: 7-25. 
Seville, C. (2006). The Internationalisation of Copyright Law: Books, Buccaneers, and the Black Flag in the Nineteenth Century. Cambridge: Cambridge University Press.

Spoo, R. (2013). Without Copyrights: Piracy, Publishing, and the Public Domain. New York: Oxford University Press.

Sprigman, Ch. (2004). Reform(aliz)ing copyright. Stanford Law Review 57: 485-568.

Stern, S. (2012). 'Room for One More': the metaphorics of physical space in the eighteenth-century copyright debate. Law \& Literature 24(2): 113-150.

Wilf, S. (2013). Intellectual property, [in:] S.E. Hadden, A.L. Brophy (eds.), A Companion to American Legal History. Oxford: Wiley-Blackwell: 441-459.

\section{FROM PUBLIC DOMAIN TO PUBLIC INTEREST}

\section{$\mathrm{S} u \mathrm{~m}$ m a r y}

This brief essay is an exploration of how the public domain came to achieve its place as a focus of attention, how it shaped a generation of scholars, and why public interest might be a more salient construct for thinking about how to foster a public-directed system of global knowledge governance. In short, this is the story of the rise, fall, and reincarnation - as public interest - of the public domain.

Keywords: public domain; public interest; Eldred v. Ashcroft; Golan v. Holder 